\title{
The Effect of Gender on the Patterns of Classroom Interaction
}

\author{
Nasser Rashidi", Sahar Naderi
}

Shiraz University

\begin{abstract}
The objective of the present study is to explore the effect of gender on the patterns of classroom interactions between teachers and students in Iranian EFL classrooms. Twenty four classes were observed, recorded and the transcripts were produced. Frequency and percentage of discourse acts produced by male and female teachers on one hand, and male and female students on the other hand, were computed and compared with each other. Chi-square tests were run to diagnose the significant differences. According to the results of the study, although males and females shared some features, the patterns of teacher-student interactions were gender related. Female teachers were more interactive, supportive and patient with their students than male teachers. They asked more referential questions, gave more compliments and used less directive forms. On the other hand, the patterns of Student-Teacher Talk were also affected by the gender of students. While male students initiated more exchanges with their teachers, female students preferred to be addressed by their teachers. Male students also made more humor and gave more feedback to their teachers.
\end{abstract}

Keywords Gender, Classroom Interaction, Gender-Related Classroom Discourse

\section{Introduction}

It has been generally assumed that gender is an affecting factor in the process of teacher/student interactions in the classroom. In other words, gender of both teachers and students influences the quality and the quantity of the interactions in the classroom. The research published from the 1960 s to the 1990s indicated that teachers' treatment toward male and female students in pre-college and college level classrooms is unequal (Sadker \& Sadker, 1992; Tannen, 1991). Actually, college teachers have been found to ask male students higher-order questions demanding critical thought (Sadker \& Sadker, 1992), make eye contacts more frequently with males than with females (Thorne, 1979), allow their classrooms to be male-dominated by calling on males more frequently (Thorne, 1979), allow males to interrupt females (Hall, 1982), and respond to males with attention and females with diffidence (Hall, 1982). Teachers of both genders also frequently give male students more interaction time than female students (Sadker \& Sadker, 1992), and initiate more contact with male students than with female students. As Sadker (1999) said, Classroom interactions between teachers and students put males in the spotlight, and relegate females to the sidelines, or to invisibility.

Besides, carrying out a meta-analysis of 81 studies on

* Corresponding author:

nrashidi@rose.shirazu.ac.ir (Nasser Rashidi)

Published online at http://journal.sapub.org/edu

Copyright $(\subset) 2012$ Scientific \& Academic Publishing. All Rights Reserved gender differences in teacher-student interaction, Kelly (1988) concluded that teachers tended to interact more with boys than girls both in teacher and student initiated interaction. Teachers asked boys much more questions and provided them more response opportunities. In other words, Kelly came to this result that teachers totally pay more attention to boys than girls and this fact exist in a wide range of classroom contexts including EFL \& ESL. Consistent with the most of the obtained results, Dale Spender (1982) also found her classroom interactions gender-biased since she was spending a minimum of $58 \%$ of her classroom time interacting with boys and a maximum of $42 \%$, and an average of $38 \%$, of her time interacting with girls.

Gender of the teacher also affects the classroom environment (Canada and Pringle, 1995; Hopf and Hatzichristoo, 1999; Duffy, et.al. 2002). According to the studies that have been done in this area, teachers of different gender have classes with different characteristics. For example, the general characteristics of a class taught by a male teacher were faster-paced, much (excessive) teacher floor time, sudden topic shifts, and shorter but more frequent student turns. Similarly, female teachers were described as communicative facilitators and perhaps more tolerant of first language use. Female teachers were also described as too forceful in choosing topics and asking too many questions primarily with the intent to smooth and perpetuate the conversational flow (Chavez, 2000).

In spite of all these differences among female and male teachers' behaviors in the classroom, Doray (2005) and Rashidi and Rafiee Rad (2010), in their studies of classroom 
interaction in Australia and Iran, respectively, revealed that male and female teachers had a lot in common in their patterns of classroom discourse supporting the notion that the choice of discourse feature was dependent firstly on the context and secondly on the role of interaction vis-à-vis each other in the community of practice.

Male and female students were also different from each other regarding their patterns of interactions with their teachers. For example, most of the studies, whether they have been made in the far past such as Meece (1987) or done more recently like Francis (2004) have indicated that boys contribute more to classroom interaction than girls. It has been, actually, argued that teachers may interact more with male students because male students respond to and initiate conversation with their teachers more than female students (Meece, 1987). Put it in another way, since male students interact more in the classroom, teachers are caused to make interaction more with male students rather than female students (Duffy, et.al. 2002). As Rashidi and Rafiee Rad (2010) observed in Iranian context, boys were more likely to interact with their teachers. Male students, however, tended to be volunteer to answer the questions, even if they do not know the right answer. Similarly, they report being more likely to take longer turns.

Nevertheless, Chavez (2000) found that female students tended to use humor less than males. Female students were more concerned with pleasing the teacher or meeting expectations. Female students reported taking shorter (more fragmentary) turns, but being more likely to be addressed in complete sentences by the teacher. On the whole, teachers and female students seem to form stronger cooperative units than teachers and male students: teachers were reported to be more likely to call on female students; female students more than their male peers enjoyed interaction with the teacher and took notes of the teacher's presentation.

Putting all these studies together, however, it is not very clear to what extent gender affects classroom interaction as there are some controversies among the results of the studies. While some studies have illustrated that male and female teachers do act similarly in their classes and even the gender of their students does not affect their methods of teaching and their behavior in their classes, there are many others that emphasized the many discriminations that have been caused by the gender of both students and teachers. These discriminations and biases, indeed, can impress the quality of teaching and learning either in a positive way or a negative way. In addition, since the matter of gender has been considered differently in different countries and people from different cultures have different views toward it, the results of the studies in other cultures cannot be generalized to other contexts especially to an Islamic context like Iran where the gender has an essential role in social issues. Therefore more studies in this area are needed in order to make the situation clearer.

As a result, the objective of the present study is to analyze classroom discourse in Iranian EFL classrooms by examining the effect of gender, both students' and teachers', on the patterns of interaction occurred in the classes. The questions are:

1. In their interactions with their students, are male and female teachers different from each other?

2. How are the patterns of classroom interactions (Student-Teacher Talk) affected by the gender of students?

3. Is classroom discourse a gender-related phenomenon?

\section{Methodology}

\subsection{The Participants}

24 teachers and their 358 students in 24 classes in Bahar Institute took part in this study. Twelve teachers were male and twelve teachers were female. Classes were either single-gendered or mixed gendered. Eight of single-gendered classes were for boys which were taught by male teachers. The other eight classes were for girls which were conducted by female teachers. The other eight classes were mixedgendered; four males and four females taught the classes. Students were considered as adult learners of the language ranging from 16 to 48 . Availability was the main criteria of subject selection. However, classes were chosen in a way that equal number of single-gendered and mixed-gendered classes took part in the study.

Table 2.2. The number and the gender of the participants

\begin{tabular}{|c|c|c|c|}
\hline No. gender & Male & Female & Total \\
\hline Students & 172 & 168 & 358 \\
\hline Teachers & 12 & 12 & 24 \\
\hline
\end{tabular}

\subsection{Data Collection Procedure}

The process of data collection was comprised of two steps. The first step included the observation of classes and tape-recording the classroom conversations in which the researcher was present as a non-participant observer. Totally, 27 classes were observed and audio-taped. Each class lasted about 105 minutes. However, for data analysis, among the 27 recorded classes, 24 classes were chosen according to their degree of clarity and relevance. This means that three classes were left out of analysis since their qualities were not sufficient enough to be used in the study. Transcribing the collected data was the second step. Consequently, about 2520 minutes ( 42 hours) of classroom interaction were transcribed. Afterwards, three classes $(10 \%$ of the whole data) were codified by the researcher. These three classes were chosen randomly. After two weeks, the same data were coded again by the researcher herself. Using a correlational analysis, the intra-coder reliability of the transcribed data was calculated $(\mathrm{r}=.991)$.

\subsection{Data Analysis Procedure}

Tsui's (1994) framework was used as the theoretical framework of this study. Focusing on the linguistic features of conversation in relation to the context of situation in which the language is used, Tsui uses the criteria of "struc- 
tural location" and "prospected response" and the concepts of act, move and exchange following Sinclair and Coulthard (1975) to analyze English conversation.

Table 2.1. Taxonomy of discourse acts proposed by Tsui (1994)

\begin{tabular}{|c|c|c|c|}
\hline & Head Acts & \multicolumn{2}{|c|}{ Subclasses of Acts } \\
\hline \multirow{22}{*}{ Initiating Acts } & \multirow{6}{*}{ Elicitations } & \multicolumn{2}{|c|}{ Elicit: agree } \\
\hline & & \multicolumn{2}{|c|}{ Elicit: repeat } \\
\hline & & \multicolumn{2}{|c|}{ Elicit: Confirm } \\
\hline & & \multicolumn{2}{|c|}{ Elicit: Commit } \\
\hline & & \multicolumn{2}{|c|}{ Elicit: Clarify } \\
\hline & & \multicolumn{2}{|c|}{ Elicit: Inform } \\
\hline & \multirow{5}{*}{ Requestives } & \multicolumn{2}{|c|}{ Request for Action } \\
\hline & & \multicolumn{2}{|c|}{ Request for Permission } \\
\hline & & \multicolumn{2}{|c|}{ Proposal } \\
\hline & & \multirow{2}{*}{\multicolumn{2}{|c|}{$\begin{array}{l}\text { Invite } \\
\text { Offer }\end{array}$}} \\
\hline & & & ffer \\
\hline & \multirow{4}{*}{ Directives } & \multirow{2}{*}{ Mandatives } & Instruction \\
\hline & & & Threat \\
\hline & & \multirow{2}{*}{ Advisives } & Advice \\
\hline & & & Warn \\
\hline & \multirow{7}{*}{ Informatives } & \multirow{5}{*}{ Assessment } & Assessing \\
\hline & & & Criticism \\
\hline & & & Compliment \\
\hline & & & Self-denigration \\
\hline & & & $\begin{array}{c}\text { Self- commen- } \\
\text { dation }\end{array}$ \\
\hline & & \multicolumn{2}{|r|}{ Report } \\
\hline & & \multicolumn{2}{|c|}{ Expressive } \\
\hline \multirow{3}{*}{ Responses } & & \multicolumn{2}{|c|}{ Positive Response } \\
\hline & \multicolumn{3}{|c|}{ Negative response } \\
\hline & \multicolumn{3}{|c|}{ Temporization } \\
\hline \multirow{3}{*}{ Follow up acts } & \multicolumn{3}{|c|}{ Endorsement } \\
\hline & \multirow{2}{*}{\multicolumn{3}{|c|}{$\begin{array}{c}\text { Concession } \\
\text { Acknowledgment }\end{array}$}} \\
\hline & & & \\
\hline $\begin{array}{l}\text { Follow up } \\
\text { Acts II }\end{array}$ & \multicolumn{3}{|c|}{ Turn passing } \\
\hline
\end{tabular}

According to Tsui (1994), three-part exchange made up of three moves (initiation, response and follow-up) is the basic unit of conversational organization whether in or out of the classroom. Each of these moves can be made up of more than one act. When a move consists of more than one act, then one of the acts is the main act that is called the 'head act' and carries the discourse function of the entire move. The class of acts occurring at the head of the initiating move can be categorized as initiating acts, that occurring at the head of responding move is named responding acts, and that occurring at the head of the follow up move can be identified as follow up acts. In turn, each of these classes of acts has their own subclasses. This framework is clarified in detail in Table 2.1 .

In sum, the transcribed data were analyzed in detail, using Tsui's (1994) model. All the classroom interactions were classified into two groups; Teacher-student talk and Student-teacher talk. Tsui's framework was used to analyze both Teacher-Student Talk and Student-Teacher Talk in the classroom. In order to investigate the effect of gender on the patterns of classroom interaction, frequency counts and percentage devices were reported. Chi-square tests were run in order to see whether the difference in the occurrence of discourse acts in male and female talks were significant or not.

\section{Results and Discussions}

\subsection{The effect of gender on the patterns of Teacher-Student Interactions}

As mentioned in the previous part, the frequency and percentage of each act produced by male and female teachers were counted and computed. The obtained results are reported in Table 3.1. It is important to know that the frequency and percentage of acts produced by 12 female teachers in single-gender and mixed-gender classes together were compared with the frequency and percentage of acts occurred in male teachers' talks in the other 12 classes.

According to the above table, regarding the use of some acts such as 'Elicit: confirm', 'repot', 'positive and negative response', male and female teachers were somehow the same. However, there were some differences between male and female teachers in using some specific acts. For example, male teachers showed preference to the act of 'Elicit: Repeat'. Actually, about $78 \%$ of all 'Elicit: Repeats' occurred by male teachers while female teachers only used about $20 \%$ of all 'Elicit: repeats'. There was also a difference between the occurrence of display and referential questions. While male teachers preferred to use more display questions (About $57 \%$ of all display questions), females employed more referential questions ( $63.4 \%$ of all referential questions) in order to interact with their students. By and large, female teachers were more interactive with their students and tried to encourage their students to talk and interact with other students by assigning different peer/group-work activities. Female students were also more interested in those activities than their male peers. Using many display questions made shorter but more frequent exchanges between teacher and students, one of the characteristics of classes taught by male teachers in our study. This is the feature that Chavez (2000) also used to describe the classes conducted by male teachers. Regarding the instructions, male teachers used more directives $(55.2 \%)$ than their female peers $(44.6 \%)$. Although female teachers used directives as well, most of the directives produced by them were in the form of requestives. Their motivation is surely Politeness. Generally speaking, girls and women tend to favor more polite and less direct forms of directives than males (Holmes, 1992). Another category which was used by males very frequently was warning. In fact, more than $77 \%$ of warnings in the classrooms were produced by male teachers. In addition, males did not give compliments to their students. Actually, no instances of compliments were found in the interactions between male teachers and their students $(0 \%)$. On the other hand, female teachers made use of compliments and expressives more frequently. By giving compliments to their students, female teachers tried to make a rapport with their students in their classes. It is interesting to know that female teachers gave their compliments only to female students. Due to Iranian culture, it is not very common that a woman gives compliment to the opposite sex or vice versa. While, females tried to give feedback to their students in the form of 
positive evaluations (54.2\% of all positive evaluations), males preferred to provide their students with acknowledgements (about $58 \%$ of all acknowledgements). Rashidi and Rafiee Rad (2010) also indicated that female teachers were more supportive than male teachers since they gave more positive feedbacks to the students.

All these differences between the use of discourse acts by male and female teachers can lead us to conclude that male and female teachers had classes with different characteristics and there was a difference in their patterns of interaction with their students. In order to find whether this difference was statistically significant, a Chi-square test was run which investigated the association between teachers' gender and their use of discourse acts.

In this case, the reported significant value is $.000(\mathrm{p}<.05)$. This means that the portion of discourse acts used by male teachers was significantly different from the portion of discourse acts used by female teachers. As a case in point, there was a significant difference between the number of positive evaluations given to the students by male and female teachers.

In sum, taking into consideration the results of the study done on the relationship between teacher's gender and Teacher-Student interaction, we came to this conclusion that the difference in Teacher-Student interaction between male and female teachers is not accidentally significant. Patterns of teacher-student talk are gender-related and teachers with different gender have different behaviors in their classes. These results are consistent with findings of Canada and Pringle (1995), Chavez (2000), Hopf and Hatzichristoo (1988), Sadker and sadker (1992) and Tannen (1991). However, this is in contrast to what Doray (2005) and Rashidi and Rafee Rad (2010) found. Some of the features shared by male and female teachers are summarized in Table 4.11 .

\subsection{The Effect of Gender on the Patterns of Student-Teacher Talk}

In addition to the studies that investigated the way teachers with different genders interact with their students, there were some other studies which explored the impact of gender on learners' behavior in the classrooms. Most of these studies have indicated that female and male students have different patterns of interaction in classrooms (Chavez, 2000).

At first, it should be mentioned that in all classes, only the number of responses that each student gave to the teacher was counted. In other words, the responses that were given by the whole class to the teachers were not counted.

Table 4.9. The frequency and percentage of each act produced by male and female teachers

\begin{tabular}{|c|c|c|c|c|c|c|c|c|c|c|c|c|}
\hline Head Acts & & & & $\begin{array}{l}\text { Total No. } \\
\text { of acts in } \\
24 \text { classes }\end{array}$ & $\begin{array}{l}\text { Fe. T } \\
\text { Fe. Ss }\end{array}$ & Per. \% & $\begin{array}{l}\text { Male T } \\
\text { Male Ss }\end{array}$ & Per.\% & $\begin{array}{c}\text { Fe. T } \\
\text { Mixed } \\
\text { gender Ss }\end{array}$ & per. $\%$ & $\begin{array}{c}\text { Male T } \\
\text { Mixed-Ge } \\
\text { nder Ss } \\
\end{array}$ & Per.\% \\
\hline \multirow{7}{*}{ Elicitation } & \multicolumn{2}{|c|}{ Elicit: Agree } & & 131 & 52 & $39.6 \%$ & 22 & $16.7 \%$ & 32 & $24.4 \%$ & 25 & $19 \%$ \\
\hline & \multicolumn{2}{|c|}{ Elicit: Repeat } & & 90 & 11 & $12.2 \%$ & 44 & $48.8 \%$ & 8 & $8.8 \%$ & 27 & $30 \%$ \\
\hline & \multicolumn{2}{|c|}{ Elicit: Confirm } & & 73 & 32 & $43.8 \%$ & 19 & $26 \%$ & 12 & $16.4 \%$ & 10 & $13.6 \%$ \\
\hline & \multicolumn{2}{|c|}{ Elicit: Clarify } & & 44 & 14 & $31.8 \%$ & 13 & $29.5 \%$ & 9 & $20.4 \%$ & 8 & $18.1 \%$ \\
\hline & \multirow{3}{*}{\multicolumn{2}{|c|}{ Elicit: Inform }} & Display Qs* & 1808 & 508 & $28 \%$ & 661 & $36.5 \%$ & 269 & $14.8 \%$ & 370 & $20.4 \%$ \\
\hline & & & Ref. Qs* & 892 & 323 & $36.2 \%$ & 180 & $20.1 \%$ & 243 & $27.2 \%$ & 146 & $16.3 \%$ \\
\hline & & & Checks* & 382 & 120 & $31.4 \%$ & 78 & $20.4 \%$ & 101 & $26.4 \%$ & 83 & $21.7 \%$ \\
\hline \multirow{4}{*}{ Directives } & \multirow{2}{*}{\multicolumn{2}{|c|}{ Mandatives }} & Instruction & 895 & 277 & $30.9 \%$ & 331 & $36.9 \%$ & 123 & $13.7 \%$ & 164 & $18.3 \%$ \\
\hline & & & Threat & 2 & 0 & $0 \%$ & 1 & $50 \%$ & 1 & $50 \%$ & 0 & $0 \%$ \\
\hline & \multirow{2}{*}{\multicolumn{2}{|c|}{ Advisives }} & Advice & 90 & 22 & $24.4 \%$ & 35 & $38.8 \%$ & 15 & $16.6 \%$ & 18 & $20 \%$ \\
\hline & & & Warn & 20 & 0 & $0 \%$ & 15 & $75 \%$ & 3 & $3.3 \%$ & 2 & $2.2 \%$ \\
\hline \multirow{5}{*}{ Informative } & \multirow{3}{*}{\multicolumn{2}{|c|}{ Assessment }} & Ass. & 58 & 25 & $43.1 \%$ & 13 & $22.4 \%$ & 14 & $24.1 \%$ & 6 & $10.3 \%$ \\
\hline & & & Crit. & 19 & 4 & $21 \%$ & 3 & $15.7 \%$ & 10 & $52.6 \%$ & 2 & $10.5 \%$ \\
\hline & & & Compli. & 5 & 1 & $20 \%$ & 0 & $0 \%$ & 4 & $80 \%$ & 0 & $0 \%$ \\
\hline & \multicolumn{2}{|c|}{ Report } & & 548 & 168 & $30.6 \%$ & 166 & $30.2 \%$ & 97 & $17.7 \%$ & 117 & $21.3 \%$ \\
\hline & \multicolumn{2}{|c|}{ Expressive } & & 104 & 44 & $42.3 \%$ & 14 & $13.4 \%$ & 30 & $28.8 \%$ & 16 & $15.3 \%$ \\
\hline \multirow{3}{*}{ Responses } & \multicolumn{3}{|c|}{ Positive Response } & 646 & 178 & $27.5 \%$ & 255 & $39.4 \%$ & 120 & $18.5 \%$ & 93 & $14.3 \%$ \\
\hline & \multicolumn{3}{|c|}{ Negative Response } & 46 & 4 & $8.6 \%$ & 9 & $19.5 \%$ & 21 & $45.6 \%$ & 12 & $26 \%$ \\
\hline & \multicolumn{3}{|c|}{ Temporization } & 2 & 0 & $0 \%$ & 1 & $50 \%$ & 0 & $0 \%$ & 1 & $50 \%$ \\
\hline \multirow{6}{*}{$\begin{array}{l}\text { Follow up } \\
\text { acts }\end{array}$} & \multirow{2}{*}{$\begin{array}{c}\text { Evalua- } \\
\text { tion } \\
\end{array}$} & \multicolumn{2}{|c|}{ Positive Eval.* } & 770 & 282 & $36.6 \%$ & 252 & $32.7 \%$ & 136 & $17.6 \%$ & 100 & $12.9 \%$ \\
\hline & & & ative Eval.* & 247 & 60 & $24.2 \%$ & 101 & $40.8 \%$ & 27 & $10.9 \%$ & 59 & $23.8 \%$ \\
\hline & \multicolumn{3}{|c|}{ Comment* } & 236 & 83 & $35.1 \%$ & 49 & $20.7 \%$ & 56 & $23.7 \%$ & 48 & $20.3 \%$ \\
\hline & \multicolumn{3}{|c|}{ Concession } & 27 & 8 & $29.6 \%$ & 6 & $22.2 \%$ & 3 & $11.1 \%$ & 10 & $37 \%$ \\
\hline & \multicolumn{3}{|c|}{ Acknowledgment } & 2140 & 430 & $20 \%$ & 783 & $36.5 \%$ & 464 & $21.6 \%$ & 463 & $21.6 \%$ \\
\hline & \multicolumn{3}{|c|}{ Repair* } & 109 & 35 & $32.1 \%$ & 36 & $33 \%$ & 12 & $11 \%$ & 26 & $23.8 \%$ \\
\hline
\end{tabular}


Table 4.10. Chi-Square test for gender and occurrence of discourse acts in male and female teachers' talks

\begin{tabular}{|c|c|c|c|}
\hline & Value & df & $\begin{array}{c}\text { Asymp. Sig. } \\
\text { (2-sided) }\end{array}$ \\
\hline Pearson Chi-Square & $2.966 \mathrm{E} 2 \mathrm{a}$ & 24 & .000 \\
\hline Likelihood Ratio & 304.430 & 24 & .000 \\
\hline Linear-by-Linear Association & 16.578 & 1 & .000 \\
\hline N of Valid Cases & 9384 & & \\
\hline
\end{tabular}

Table 4.11. Interactional features of male and female teachers

\begin{tabular}{|c|c|}
\hline Male Teachers & Female Teachers \\
\hline 1. Use Display questions more & 1. Use Referential questions more \\
\hline 2. Talk about current issues & 2. Follow the topics of the textbook \\
\hline 3.Use more directive forms & 3. Use less directive forms \\
\hline 4.Switch to the native language & 4. Less tolerant of native language \\
\hline 5. More acknowledgement & 5. More evaluations \\
\hline 6.More warning & 6. More patient and supportive \\
\hline & $\begin{array}{c}\text { 7. Give more compliments to the } \\
\text { students }\end{array}$ \\
\hline
\end{tabular}

According to table 4.11, there are again differences and similarities between female and male students. For instance, while students were somehow similar in eliciting confirmation or clarification from their teachers, they were different in eliciting information. Based on the frequency and percentage indices reported in the above table, boys were tended to ask more questions than their female peers especially in the mixed-gender classes. By contrast, girls responded teachers' elicitations more in those classes. In addition, boys usually provided their teachers with short answers. By contrast, female students' responses were longer and more sophisticated. In other words, girls used new words and new grammar patterns they learned in their talk. Boys also used more 'Elicit: repeat' than girls (male students used about $86 \%$ of all Elicit: repeats). In this respect, boys looked like teachers with the same gender. Regarding the use of feedbacks, these were the boys who gave most of the feedbacks to their teachers whether in the form of thanking $(76.1 \%)$ or acknowledgement $(68.3 \%)$. This can be related to the fact that they also asked more questions or requested more than female students. They also tended to interact with their teachers more than girls. While girls had a tendency to stop and pass the conversation to their teachers or other students (about $60 \%$ of the second follow up occurred in girls' talks), boys tried to make the floor and initiate the conversations with their teachers. Since female students preferred to talk with their peers, boys were more interested in interacting with their teachers. Finally, only boys criticized their teachers and provided their teachers with different suggestions and recommendations. Female students, neither in single-gender nor in mixed-gender classes used the acts of 'criticism' in their talks with their teachers.

Comparing the behavior of female and male students in mixed gender classes, we came to this conclusion that male students used most of the acts more frequently than their female peers. There were only some categories such as 'expressive' that female students often used. In mixed gender classes, female students initiated the conversations much less than males although they produced more responses to their teachers' initiations. Although girls reported events or expressed their opinions in single-gender classes more often than boys, these were the boys who tended to report events and express their ideas more than girls in mixed-gender classes. This is completely consistent with the findings of Canada and Pringle (1995) who studied gender differences in mixed-gender classrooms.

Table 4.12. The frequency and percentage of each discourse act produced by male and female students

\begin{tabular}{|c|c|c|c|c|c|c|c|c|c|c|}
\hline Head Acts & & & $\begin{array}{l}\text { Fe. Ss in } \\
\text { single- g } \\
\text { classes }\end{array}$ & Per. \% & $\begin{array}{c}\text { Male Ss in } \\
\text { Single -g } \\
\text { classes }\end{array}$ & Per.\% & $\begin{array}{c}\text { Fe. Ss in } \\
\text { Mixed gender } \\
\text { classes } \\
\end{array}$ & per. $\%$ & $\begin{array}{l}\text { Male Ss in } \\
\text { Mixed- Gen- } \\
\text { der classes }\end{array}$ & Per.\% \\
\hline \multirow{4}{*}{ Elicitations } & Elicit: Repeat & & 1 & $6.6 \%$ & 10 & $66.6 \%$ & 1 & $6.6 \%$ & 3 & $20 \%$ \\
\hline & Elicit: Confirm & & 13 & $30.9 \%$ & 20 & $47.6 \%$ & 1 & $2.3 \%$ & 8 & $19 \%$ \\
\hline & Elicit: Clarify & & 2 & $50 \%$ & 2 & $50 \%$ & 0 & $0 \%$ & 0 & $0 \%$ \\
\hline & Elicit: Inform & & 112 & $27.5 \%$ & 161 & $39.5 \%$ & 49 & $12 \%$ & 85 & $20 \%$ \\
\hline \multirow[b]{2}{*}{ Requestive } & Request for action & & 6 & $37.5 \%$ & 3 & $18.7 \%$ & 3 & $18.7 \%$ & 4 & $25 \%$ \\
\hline & $\begin{array}{l}\text { Request for per- } \\
\text { mission }\end{array}$ & & 18 & $31 \%$ & 23 & $39.6 \%$ & 1 & $1.7 \%$ & 16 & $27.5 \%$ \\
\hline Directives & Advisives & Advice & 1 & $20 \%$ & 0 & $0 \%$ & 0 & $0 \%$ & 4 & $80 \%$ \\
\hline \multirow{4}{*}{ Informative } & \multirow{2}{*}{ Assessment } & Assessing & 13 & 32.5 & 12 & $30 \%$ & 8 & $20 \%$ & 7 & $17.5 \%$ \\
\hline & & Criticism & 0 & $0 \%$ & 8 & $80 \%$ & 0 & $0 \%$ & 2 & $20 \%$ \\
\hline & Report & & 74 & $38.1 \%$ & 45 & $23.1 \%$ & 35 & $18 \%$ & 40 & $20.6 \%$ \\
\hline & Expressive & & 10 & $37 \%$ & 9 & $33.3 \%$ & 7 & $25.9 \%$ & 1 & $3.7 \%$ \\
\hline \multirow{3}{*}{ Responses } & \multicolumn{2}{|c|}{ Positive Response } & 1451 & $30.7 \%$ & 1808 & $38.3 \%$ & 837 & $17.7 \%$ & 619 & $13.1 \%$ \\
\hline & \multicolumn{2}{|c|}{ Negative Response } & 90 & $40.3 \%$ & 70 & $31.3 \%$ & 32 & $14.3 \%$ & 31 & $13.9 \%$ \\
\hline & \multicolumn{2}{|c|}{ Self repair } & 17 & $22 \%$ & 34 & $44.1 \%$ & 17 & $22 \%$ & 9 & $11.6 \%$ \\
\hline \multirow{2}{*}{ Follow up } & \multicolumn{2}{|c|}{ Endorsement } & 4 & $19 \%$ & 10 & $47.6 \%$ & 1 & $4.7 \%$ & 6 & $28.5 \%$ \\
\hline & \multicolumn{2}{|c|}{ Acknowledgment } & 21 & $27.6 \%$ & 27 & $35.5 \%$ & 3 & $3.9 \%$ & 25 & 32.8 \\
\hline \multirow{2}{*}{$\begin{array}{c}\text { Follow up } \\
\text { II }\end{array}$} & \multicolumn{2}{|c|}{ Turn passing } & 23 & $31.5 \%$ & 16 & $21.9 \%$ & 21 & $28.7 \%$ & 13 & $17.8 \%$ \\
\hline & \multicolumn{2}{|c|}{ Acknowledgement II } & 33 & $40.7 \%$ & 27 & $33.3 \%$ & 11 & $13.5 \%$ & 10 & $12.3 \%$ \\
\hline
\end{tabular}


Table 4.13. Interactional features of male and female students

\begin{tabular}{|l|l|}
\hline \multicolumn{1}{|c|}{ Male Students } & \multicolumn{1}{|c|}{ Female Students } \\
\hline 1. Initiate more exchanges & 1. Prefer to be respondent, to be asked or called by the teacher \\
\hline 2. give short answers & 2. provide longer responds \\
\hline 3.Like to make the floor and continue the conversation & 3. Use new grammar and words they have learnt \\
\hline 4.Use humor & 4. Prefer to stop or pass the conversation (Turn Passing Act) \\
\hline 5. Give more feedback to the teacher & 5. Switch to native language more \\
\hline 6.Criticize teacher, give suggestions and recommendations & 6. Interested in the activity itself \\
\hline 7. Interested more in pre or post activities & \\
\hline
\end{tabular}

In addition, it was observed that girls tended to switch to their native language more than boys. While boys insisted on speaking in the target language and making them understood (they did not mind how much time it took), girls quickly switched to the native language and tried to end the conversation. Female teachers, however, were less tolerant of native language. This is the motivation of most of their criticism toward their students (Table 4.9.). On the other hand, male teachers themselves made use of Persian, their native language, very frequently. In the classrooms, boys were more humorous than girls. Teachers also used more humor with boys, especially in Mixed-gender classes, since boys were more tolerant of humor. Besides, although girls preferred to work on the topics of their books, boys seemed to be more interested in topics outside of their classrooms; topics related to the current social and political issues. It was observed that, especially in mixed-gender classes, boys were more active in pre- and post- activities, (like reading activities) while girls were more interested in the activity itself. These differences are summarized in Table 4.13.

In order to understand the association between students' gender and Student-Teacher interaction, a Chi-Square was applied. The variables of the first test were students' gender and discourse acts.

Table 4.14. Chi-Square test for the occurrence of discourse acts in male and female students' talks

\begin{tabular}{|c|c|c|c|}
\hline & Value & $\mathrm{df}$ & $\begin{array}{c}\text { Asymp. Sig. } \\
\text { (2-sided) }\end{array}$ \\
\hline Pearson Chi-Square & $70.891 \mathrm{a}$ & 17 & .000 \\
\hline Likelihood Ratio & 76.673 & 17 & .000 \\
\hline Linear-by-Linear Association & 17.932 & 1 & .000 \\
\hline N of Valid Cases & 6084 & & \\
\hline
\end{tabular}

In this case, as the significance reported by the computer is $.000(\mathrm{p}<.05)$, we can conclude that the difference between male and female students' utterances in the classroom is also significant. This means that the patterns of student-teacher talk are affected by the gender of students and students with different gender interact with their teachers in different ways. This is similar to the findings of other researchers like Canada and Pringle (1995) and Chavez (2000).

\section{Discussion}

In sum, taking into consideration the results of the study done on the relationship between teacher's gender and Teacher-Student interaction, we came to this conclusion that patterns of Teacher-Student talk are gender-related and male and female teachers have different behaviors in their classes. While male teachers used many display questions, female teachers asked more referential questions. Female teachers were more interactive with their students either in single-gender or mixed-gender classes. In mixed gender classes, male teachers were more interactive with boys than girls. These findings were supported by the findings of Thorne (1979) and Sadker \& Sadker (1992). Female teachers were also more supportive and patient. They gave more compliments to their students and used less directive forms. Therefore, gender affects the Teacher-Student interaction. Other researchers who found classroom interactions gender-related are Canada and Pringle (1995), Francis (2004), Hopf and Hatzichristoo (1999), Kelly (1988) and Shomoosi et.al (2008). The result of the study is, however, inconsistent with the result of Rashidi and Rafiee Rad's (2010). The reason may be that her study investigated only single-gender classes while this study works on both single and mixedgender classes.

The difference between male and female students' utterances in the classroom is also significant. This means that the patterns of student-teacher talk are affected by the gender of students and students with different gender interact with their teachers in different ways (Chavez, 2000). In mixed-gender classes, male students initiated more exchanges with their teachers, made more humor and gave more feedback to their teachers. Consistent with the results of Shomoossi, et.al.'s study (2008), our study also indicated that

pupils play an active part in bringing the gender differences in classroom

interaction into being: boys are more likely than girls to create conditions

where their contributions will be sought by teachers, and they are more

likely than girls to push themselves forward when contributors are not

explicitly selected. However, this is not to say that teachers are entirely

passive in the process (Shomoossi, et.al. 2008, p. 180)

Of course, gender cannot be the only factor influencing classroom interaction. As Tannen (1996b) said, classroom interaction might be affected by a group of factors such as race, class context, and age differences along with sexual orientation, professional training, and individual personality. However, although it is difficult, we should try to eliminate the discriminations that are caused by gender in our classes. As Jones (2000) has found, fortunately, unequal treatment of girls and boys can be decreased through training and 
self-analysis of video recordings of classroom teaching.

\section{Conclusions}

In sum, analyzing the classroom discourse according to the gender of students and teachers, we found that

1. In their interactions with their students, are male and female teachers different from each other?

Yes. According to the results of the study, male and female teachers are different from each other while they interact with their students. In other words, there is a great difference between the behavior of men and women (teachers) in the classrooms. To give some examples, male teachers used many display questions but female teachers asked more referential questions which promoted more interactions between the students and the teacher. Female teachers were more interactive with their students both in single-gender and mixed-gender classes; they encouraged different interactive tasks such as peer and group works in their classes. Female teachers were also more supportive and patient. They gave more compliments to their students and used less directive forms. Other researchers who found classroom interactions gender-related are Canada and Pringle (1995), Hopf and Hatzichristoo (1999) and Kelly (1988).

2. How are the patterns of classroom interactions (Student-Teacher Talk) affected by the gender of students?

Based on the obtained results, the difference between male and female students' utterances in the classroom was also significant. This means that the patterns of Student-Teacher Talk were also affected by the gender of students (Chavez, 2000). In mixed-gender classes, male students initiated more exchanges with their teachers, made more humor and gave more feedback to their teachers.

3. Is classroom discourse a gender-related phenomenon?

All in all, we came to this conclusion that classroom discourse is gender-related to some extent (Shomoosi, et.al. 2008). In other words, gender plays an important role in the way the participants of a classroom interact with each other. However, according to Tannen (1996), gender cannot be the only factor influencing classroom discourse. Context of the classroom, students' and teachers' age, teachers' experiences and other individual personalities may have considerable influences.

\section{REFERENCES}

[1] Canada, K and Pringle, R. (1995). The role of gender in college classroom interactions: a social context approach. Sociology of Education, 68, 161-186

[2] Chavez, M. (2000). Teacher and student gender and peer group gender composition in German foreign language classroom discourse: An exploratory study. Journal of Pragmatics, 32, 1019-1058

[3] Doray, M.B.A. (2005). Gender differentiated discourse: A study of teacher discourse in the adult ESL classroom. Retrieved March, 19, 2010 from http:// espace.library. curtin.edu.au $/ \mathrm{R}$ ? func $=$ searchsimplego \& ADJACENT $=\mathrm{Y} \&$ REQUEST $=$ adt- wcu 20061011.1701750

[4] Duffy, J., Warren, K. and Walsh, M.(2002). Classroom interactions: gender of teacher, gender of student, and classroom subject. Sex roles, 45 (9/10), $579-593$

[5] Francis, B. (2004). Classroom interaction and access: Whose space is it? In Gender in Education 3-19: A Fresh Approach, ed. H. Claire, 42-49. London: Association of Teachers and Lecturers

[6] Hall, R. (1982). The classroom climate: A chilly one for women? Association of American Colleges, Project on the status of women

[7] Holmes, J. (1992). An introduction to sociolinguistics. Longman, New York

[8] Hopf, D. and Hatzichristou, C. (1999). Teacher-gender related influences in Greek Schools. British Journal of Educational Psychology, 69, 1-18

[9] Jones, K. (2000). Gender Equity Training and Teacher Behavior. Journal of Instructional Psychology, 3, 27

[10] Kelly, A. (1988). Gender differences in teacher-pupil interactions: a meta-analytic review. Research in Education, 39, $1-23$

[11] Meece, J. L. (1987). The influence of school experiences on the development of gender schemata. In L. S. Liben \& M. L. Signorella (Eds.), Children's gender schemata. (pp. 57-73). San Francisco, CA: Jossey-Bass

[12] Rashidi, N. and Rafiee Rad, M. (2010). Analyzing patterns of classroom interaction in EFL classrooms in Iran. The Journal of Asia TEFL, 7(3), 93-120

[13] Sadker, D. (1999). Gender Equity: Still Knocking at the Classroom Door. Educational Leadership, 56(7): 22-6

[14] Sadker, M. and Sadker, D. (1992). Ensuring equitable participation in college classes. In. Border L.L.B. \& Chism N.V.N. (Ed), Teaching for Diversity: New Directions for Teaching and Learning, 49-56. Jossey-Bass, San Fransisco

[15] Shomoossi,N; Amouzadeh,M and Ketabi, S. (2008). Classroom Interaction Mediated by Gender and technology: the Language Laboratory Course. Novitas-ROYAL, 2 (2), 176-184

[16] Spender, D., 1982. Invisible women: the schooling scandal. London: Writers and Readers Publishing Co-operative Society with Chameleon Editorial Group

[17] Tannen, D. (1991). Teacher's classroom strategies should recognize that males and females use language differently. Chronicle of Higher Education. 37, B1

[18] Tannen, D. (1996b). Researching gender-related patterns in classroom discourse. TESOL Quarterly, 30, 341-343

[19] Thorne, B. (1979). Claiming Verbal Space: women speech and language for college classrooms. Paper presented at the Research Conference on Educational Environments and Undergraduate Women, Wellesley College, Wellesley, MA

[20] Tsui, A.B.M. (1994). English Conversation. Oxford University Press, Oxford 